\title{
Discussion on the Teaching Strategy of Oil Painting in Colleges under the Background of Multiple Art Culture Development
}

\author{
Liming Wang \\ Shihezi University, Shihezi 832000, XinJiang, China.
}

Abstract: The development of multiculturalism is the inheritance of human civilization and the result of the further deepening of globalization. The diversified development of fine art culture is one of the main situations of fine art development. The art creation theories, conceptual methods, and painting skills, etc., all exhibit diverse characteristics. Based on this background, college oil painting teaching also needs to grasp this multicultural situation, carry out curriculum teaching reform and innovation, and promote the diversified development of fine arts education. This article introduces the development trend of multiple arts culture and its impact on domestic oil painting, analyzes the current status of oil painting teaching in colleges and universities, and explores effective countermeasures for oil painting teaching in colleges and universities in the context of multiple art culture.

Keywords: Multiple Art; Cultural Development; College Oil Painting; Teaching

Oil painting teaching is an important part of the current art teaching system in colleges and universities. This is very important for the improvement of students' painting literacy, and it will also affect the cultivation of students' artistic innovation ability. Under the current educational reform and diversified development background, college oil paintings should maintain the advanced nature of their own teaching development, and based on the diverse development background, promote the reform and innovation of fine arts teaching.

\section{The development trend of diverse art culture and its impact on domestic oil painting}

Oil painting was introduced into China from the West. After the oil painting was integrated into Chinese society, many painters have made countless explorations and practices, and achieved satisfactory results. Many excellent oil painting works have emerged to promote the development of China's painting career which made a huge contribution. But overall, the gap between the current level of oil painting in China and the international oil paintings is still relatively large, and most domestic oil painting creations tend to be conservative and traditional, so there are some closed and backward problems.

At present, in the world oil painting creation, the relevant oil painting creators are trying to transform and develop the art of oil painting from the perspective of their own culture, which further promotes the diversified movement of oil painting. Based on this, the development of Chinese oil painting also needs to be transformed with a new aesthetic form to promote the diversified development of oil painting. For the teaching of oil painting in colleges and universities, under the background of diverse art culture, it is necessary to grasp the diversified development trend of art and promote the realization of the goal of diversified development. This is of great significance to oil painting teaching.

\section{The status of oil painting teaching in colleges and universities}

\subsection{The teaching concept is backward and the teaching mode is single}

Copyright @ 2020 Liming Wang

doi: 10.18282/le.v9i6.1323

This is an open-access article distributed under the terms of the Creative Commons Attribution Non-Commercial License

(http://creativecommons.org/licenses/by-nc/4.0/), which permits unrestricted non-commercial use, distribution, and reproduction in any medium, provided the original work is properly cited. 
At present, in the teaching of oil painting in colleges and universities, influenced by traditional educational concepts, teachers have a certain deviation in the understanding of oil painting teaching, and there are also some wrong understandings. In classroom teaching, teachers put too much emphasis on realistic teaching, the teaching model is applied in a single way, and the lack of innovative research and exploration makes it difficult for students to meet individualized learning needs. Some teachers pay attention to the teaching of oil painting skills based on their own experience, and pay little attention to the cultivation of students' creative thinking in art, which causes students to fail to effectively reflect the essence of oil painting in the creation of more professional oil paintings. This has a negative effect on enhancing and exerting the resonance effect of oil paintings.

\subsection{Ignore the humanities education of students}

At present, colleges and universities carry out oil painting teaching. Teachers often focus on teaching professional content and skills. They do not pay enough attention to the humanities education of students, nor do they have a relatively complete extension of oil painting theory, which is not conducive to the overall cultural literacy of students. In addition, teachers' unclear positioning of oil painting majors' training objectives will also lead to the inability of students to improve their comprehensive literacy, and the difficulty in improving students' cultural literacy, so that their future employment will also be affected to a certain extent.

\subsection{Insufficient understanding of innovation}

Since the new century, innovation has been an important issue in college education. In the teaching of oil painting in colleges and universities, innovation has gradually been paid attention to. However, at present in China's oil painting teaching, some teachers have a misunderstanding of innovation. Some teachers simply believe that innovation is to change the traditional curriculum teaching model and emphasize innovation in teaching. In the process of learning oil painting, they add some personal habits in the course practice, resulting in students changing the painting method and colors, focusing on subjective colors and abstractionism. They regard this as innovation. But in fact, some of the teacher's practices have not played an incentive role in enhancing students' creativity and aesthetic ability, and also affected the cultivation of students' innovative thinking. This is not an innovation in the educational sense, nor is it conducive to the cultivation of innovative professionals in oil painting.

\section{The teaching countermeasures of college oil painting under the background of diverse art culture}

\subsection{Promote diversified teaching and optimize classroom teaching practice}

In the initial stage of oil painting development, based on the influence of the national conditions at that time, the oil paintings of the former Soviet Union had a greater influence on the development of oil painting in China. This preconceived oil painting creation and painting concept must be truly eliminated before the oil painting creators can better reflect the independent creation concept in the creation of works, and truly express the true feelings through oil painting works, which also has certain positive effects on the development of the national economy. Only oil paintings created based on the cultural characteristics of the Chinese nation can better promote the development of domestic oil painting. In the context of diversified culture, the development of oil painting also needs to establish a multiple development concept. In the actual oil painting teaching, teachers also need to pay attention to the application of the multi-cultural development concept. Through the innovation of multiple teaching models, teachers can help students establish a new creative concept and promote oil painting classroom teaching to achieve ideal results.

\subsection{Improve the teaching system and promote the realization of the multiple development goals of oil painting}

At present, under the background of the market economy, the realization of the diversified development goals of oil painting teaching in colleges and universities also needs to further improve the oil painting teaching system. In practical teaching, teachers should pay attention to creatively explore the educational concepts suitable for oil painting teaching. In actual oil painting teaching practice, it is possible to innovate in the teaching management model and deepen system reform. In the past, the teaching system of the studio system in oil painting teaching focused more on the training of 
students' oil painting techniques, and did not pay enough attention to the students' cultural literacy. This would easily lead to the formation of a single fixed creative model for students. Promotion is unfavorable, and it does not match the current goal of oil painting teaching in colleges and universities in China. In this regard, it is necessary for relevant universities to improve their oil painting teaching system by combining their own teaching practice and students' practice, so as to lay a solid foundation for achieving diverse teaching goals.

\subsection{Innovate teachers' teaching concepts and promote diversified teaching}

In the teaching of oil painting in colleges of fine arts in colleges and universities, teachers should innovate their own teaching concepts of oil painting. They should not be constrained by the traditional teaching model. They must be able to make bold reforms to the inherent teaching model. They should combine class teaching with class practice to encourage students to step out of the classroom into life, and create boldly. Teachers should actively learn and apply advanced curriculum teaching concepts, and encourage students to have their own ideas, thereby constantly learning and accumulating, and forming their own painting language. Students are required to correct their attitudes in the creation of oil paintings, choose a painting style that suits them, and take their majors seriously to achieve greater progress.

It should be known that the traditional curriculum teaching mode will affect students to a certain extent, and teachers' own artistic views and artistic pursuits will also affect students. Therefore, in the primary school of oil painters in colleges and universities, teachers should change their artistic conception, pay attention to the art development trend of students, set a good example for students, and constantly innovate ideas and forms in oil painting art to promote the cultivation of students' creativity in oil painting arts and enhance the comprehensive literacy of oil painting of students.

\subsection{Carry out diversified oil painting practices to enhance the ability of oil painting creation}

In the context of diverse arts and culture, it is one of the educational goals to promote the improvement of students' artistic creativity. In this regard, schools can actively organize diversified oil painting practice activities to allow students to expand their knowledge and enhance cultural literacy. For example, the weekly oil painting exhibition is held. The exhibition works are diverse in style and rich in the subject matter. They present the creative level and artistic charm of oil painters from all angles, and focus on the achievements of oil painting art creation. By providing a communication platform for students, discover and encourage talents during the exhibition, connect various oil painting art groups, strengthen communication, and broaden artistic horizons. Only by respecting the diversity of artistic concepts and artistic language, advocating pluralism and inclusive academic spirit, and fully demonstrating the latest thinking and practice of the oil painting authors can it possible to inspire students to create inspiration and enhance student culture literacy.

\section{Conclusion}

There are still some deficiencies and problems in the teaching of oil painting in colleges and universities. For this, we need to actively explore the ideas and countermeasures of oil painting teaching in light of the problems in the teaching of oil painting in colleges and universities, and promote the continuous improvement of the quality of oil painting teaching in colleges and universities.

\section{References}

1. Li B. Analyze the teaching of oil painting in colleges and universities under the background of the development of multiple art cultures. Popular Literature 2018; (06): 204-205.

2. Zhang T. Diversified integration, pioneering and innovative_-A summary of undergraduate teaching in the Department of Oil Painting, Guangzhou Academy of Fine Arts. Art Work 2017; (06): 28-30.

3. Zhu P. The cradle of realism in China__ On the oil painting art and historical value of the Art Department of Nanjing Central University during the Republic of China. Fine Arts Research 2015; (04): 74-80.

4. Yang X. Thinking about the reform of oil painting teaching in colleges from the perspective of diversified development of oil painting. Grand Stage 2012; (09): 132-133. 